\title{
Comparative Analysis on Service Quality \&Customer Satisfaction: Empirical Evidence from Pakistan Hotel Industry
}

\author{
SYED NASEEB ULLAH SHAH \\ PhD Research Scholars Institute of Business Studies and Leadership \\ Abdul Wali Khan University, Mardan \\ DR. QADAR BAKHSH BALOCH \\ Professor, Institute of Business Studies and Leadership \\ Abdul Wali Khan University, Mardan \\ qbbaloch@awkum.edu.pk
}

\begin{abstract}
The phenomenon of Quality of service, as the degree of excellence at an acceptable price, has gained a pivotal place in the success or failure of a business or gaining and maintaining customer satisfaction over the years. The research study aimedto compare the mean score of KPK, Punjab and Islamabad hotel customer's mean score and to recommend strategies for improving managerial efficiency and operational effectiveness in improvising and sustaining service quality so as to gain and sustain customer satisfaction and brand loyalty. The population included hotels having restaurants and living accommodation both, and stratified on the bases of geography located in selected cities of Khyber Pakhtunkhwa, Islamabad and Lahore. The sample of hotel, worked out on the bases of 10hotels from each location and 20 customers from each hotel, comprises of 60 hotels and 1200 customers from Khyber Pakhtunkhwa, and 20 hotels and 400 customers forum Islamabad and Lahore. The paired samples t-test used to compare the mean score difference about the customers of KPK, Punjab and Islamabad Pakistan found that there is significance difference between the mean score of Punjab and KPK customers on service quality attributes. The mean score of Punjab customers is and Islamabad customers are found that there is significance difference between the mean score for Punjab and customers on service quality attributes. The research contributes theoretically and practically to the Hotel service industry and customer satisfaction in Pakistan which is supported by the empirical evidence and would help the Pakistan's Hotel industry to improve its business performance through improving their service quality and adding in to their customer satisfaction.
\end{abstract}

Key Words: Service Quality SURVQUAL, tangibility, Hotel industry, Pakistan

\section{Introduction}

Food, accommodation and dress are the three most essential things of human. Hotel or hotel industry alone provides two basic things: food and accommodation. So, what is hotel or hotel industry?Hotel is a part of the hospitality industry which is an umbrella term for a broad variety of service industries including, but not limited to, hotels, restaurants and casinos. Hotel is often referred as a "Home away from home". If 
we consider meaning of hotel in the dictionary, a hotel is a building where you pay to have a room to sleep in and where you can eat meals (Cambridge dictionary) or a hotel is an establishment that provides paid lodging on a short-term basis (Wikipedia). According to A.M. Sheela, the author of the book "Economics of Hotel Management", hotel is the place where the tourist stops being the traveler and become a guest. Hotel usually offer a full range of accommodations and services, which may includes suites, public dinning, banquet facilities, lounges and entertainment facilities. It is considered as an industry whose main aim is also to make profits for the hoteliers, though this may change at times. Hence a hotel should provide food, beverage and lodging to travelers on payment and has in turn the right to refuse if the traveler is drunk, not follow the rule of hotels or not pay the service fee. Traditional hotels provide rooms, banquets and restaurants. Additional hotels get revenues also from telephone call services, laundry services, travel services, internet services and recreational, entertainment activities in the hotels.

The hotel is maybe one of the oldest industries in the world. The history of hotels is connected closely to civilizations of mankind.According to some documents, the first inn was appeared in the sixth century B.C when some couples provide large halls for travelers to drink and the entire service was done by owners. To other documents, since early biblical times, the Greeks developed thermal baths in villages for rest. Later, the Romans built mansions to provide accommodation for the government business. The first thermal baths in England, Switzerland and the Middle East were developed by the Romans. In the Middle Ages, religious built inns to cater for their colleagues on the move. At the beginning, inns did not offer meals. They only provided shelter and allowed horses to be changed more easily. Travelling became popular and the impact of the industrial revolution in England spread widely that led to the change from social or governmental travel to business travel. The need for quick and clean service all the time was emerged.

The birth of hotel industry took place in Europe. At the beginning of the fifteenth century, in France, the first time, there was a law required that hotels keep a register. During this period, the first guide books for travelers were also published. English rules for inns also introduced at that time. At the same time, around 1500 thermal spas were developed in Carlsbad and Marienbad.However, the real growth of the modern hotel industry took place in the USA by the opening of the City Hotel in New York in the year 1794. It emerged the wave of hotel building activity in different cities. Some of the best hotels of the USA were built in this era, but the real boom came in the early of 20th century. This period also saw a beginning of chain operations under the guidance of E.M Sattler which would spread into all the continents. It involved big investments, big profits and trained professionals to manage the hotel business. Nowadays, architects, designers, developers, engineers, managers, etc realize that taste of guests could be different, according to their wishes or needs. Therefore, they have to catch new trends, define better criteria, present modern standards in order to improve quality of life in hotels.

Due to inappropriate business performance of hotel industries and prevailing service quality, law and order situation of Pakistan the growth of hotel industry in Pakistan has been declined, consequently the customers are unable to attract from any existing and new segments of hotel industry and are not feeling satisfied. In Pakistan, the state of tourism affairs is miserable, in spite of its promising potential due to unstable law and order situation and terrorism (Al Khattab \& Aldehayyat, 2011). Pakistan was 
positioned 47 out of 200 nations in an examination of the world travel and tourism council development figures (Kandampully \& Juwaheer, 2009). The hilly areas of Pakistan namely Nathia-gali, Ghoragali, Dungagali and Murree which are near to capital city Islamabad are very peaceful areas. Tourists more frequently visited to Galiyat and Murree because of peacefulness and stable law and order situation (Al Khattab \& Aldehayyat, 2011). Recent research study conducted on hotel industry in Pakistan reported that only 98 studies that involved 114,000 respondents having identified only two published studies that examined the service quality, customer satisfaction and business performance (Al Khattab \& Aldehayyat, 2011). Moreover, Scholars reported that the concept of service quality, customer satisfaction and business performance till yet (Kandampully \& Juwaheer, 2009; Al Khattab\& Aldehayyat, 2011). The objectives of the study are to compare the mean score of KPK, Punjab and Islamabad hotel customer's mean score and to recommend strategies for improving managerial efficiency and operational effectiveness in improvising and sustaining service quality so as to gain and sustain customer satisfaction and brand loyalty. This research study serves as an economic resource multiplier for Pakistan economy in general and Khyber Pakhtunkhwa in particular as it would be helping to develop tourism a key source of foreign reserve earning.

\section{Literature Review}

The SERVQUAL is frequently used instrument in measuring service quality in the hotel business along a set of five dimensions/ variables. While developing this model Parasuraman (1985) initially listed some service related attributes which were summed into following dimensions:

\begin{tabular}{ll}
\hline \hline Tangible & Accommodation, equipment, staff uniforms \\
\hline \hline Reliability & Ability to deliver the promised service \\
Responsiveness & Readiness of staff members to help \\
Competence & Staff capability in executing the service \\
Courtesy & Respect \& Politeness by staff \\
Creditability & Professional honesty, trustworthiness of provider \\
Security & Safety from risk and physical danger \\
Access & Approachability of service providers. \\
Communication & Understanding of the communication \\
\hline \hline
\end{tabular}

Numerous studies have postulated that service quality (SERVQUAL) is multidimensional in essence for measuring hotel service quality (e.g. Knutson, et al., 1992; Amstrong et al., 1997; Choi and Chu, 1998; Ekinci\& Riley, 1998; Antilgan et al., 2003; Akbaba, 2006; Maria and Serrat, 2011). For instance, Akbaba (2006) studied the service quality of hotels in Turkey by analyzing the expectation and actual perception of service quality based on 29 characteristic indicators, which were applied from SERVQUAL, and the most important factor reflecting the overall needs of service quality measurement was tangible services. Wilkins et al (2007) also studied the service quality of hotels in Australia. The seven factors were developed from SERVQUAL, covering style and convenience, room quality, special offers, quality staff, personality, fast service, and quality food and beverages.

In addition, other research has indicated and explained that the characteristics of service quality factors and service priorities, from the customers' perspective, differed 
depending on the hotel types. Gabbie and O'Neill (1997) conducted research on the service quality of hotels in North Ireland. Their aims were to study the gaps between the expectation and the perception of service quality delivered by two 3-star hotels using 22 characteristics of SERVQUAL. The research revealed that a gap between the customer perception and the customer expectation of the first hotel that applied total quality management (TQM) was smaller than that of another one. TQM drove better performance due to employee empowerment, so the first hotel was able to satisfy customer needs more efficiently. Carrillat et al (2007) found that SERVQUAL was a well-known instrument, and became a proper measurement tool for the hotel business, one of the service businesses focusing on customer satisfaction. Salazar et al.(2010) also developed a service quality evaluation scale for the hospitality sector. Since this research study aims to investigate the service quality expectations of business hotels' customers therefore, the review of literature focused on the past researches having focus on identifying and examining various dimensions of service quality especially with reference to hotel industry. Most of the researches are found applying SERVQUAL model which revolved around the five service quality dimensions such as; tangibles, adequacy in service supply, understanding and caring, assurance, and convenience(Parasuraman, Zeithaml and Berry, 1986, 1888). Parasuraman, Berry and Zeithaml (1991) have produced a standardized questionnaire, known as 'SERVQUAL' which measures respondents' 'expectations' and 'performance' scores, and calculating service quality as the difference between them. Attilla (2006) finds that travelers had the highest expectations for the dimension of "convenience" followed by "assurance", "tangibles", adequacy in service supply", and "understanding and caring". The research also confirmed the SERVQUAL scale a very useful tool to be adapted for the specific service segments. According to Gronroos (1994) there are three dimensions of service quality, the technical quality, the function quality and the corporate image:

a. The technical quality, which involves what the customer, is receiving from the service delivery. This can be measured by the consumer in a rather objective manner.

b. Functional quality, which involves the manner in which the service is delivered. This concerns the psychological interaction between the buyer and the seller an is perceived in a very subjective way, and would include elements such as:

- Attitudes and behavior of employees;

- Approachability of service personnel;

- Accessibility of service;

- Appearance and personality of personnel;

- Relationship between employees, and;

- Interrelationships between employees and customers.

\subsection{Theoretical \& Conceptual Framework}

Based on the review of the related literature the research conceptualized the conduct of research on two tiers framework independent in their structure but reinforcing each other in their final outcomes at the response development stage: Firstly the research plans to investigate the effect of service quality towards customer's satisfaction by applying SERVQUAL and Gronroos service quality model which focuses on the relationship between variables like functional quality, technical quality, internal, external 
influences, prices corporate image and service quality towards customer's satisfaction. Wherever, customers agreed that they are satisfied and give the reasons for satisfaction as service quality dimension has significant relationship with service quality and customer satisfaction, then a conclusion is drawn that service quality has a significant relationship with customer satisfaction and with service quality dimensions. And degree of customer satisfaction leads to the corresponding degree of competitiveness or the competitive advantage in the given industry thereby resulting in to brand loyalty and profitability. Keeping in view the input from the review of the literature and analyses of various service quality measurement models, this research presents an adapted SERVQUAL model, which is believed to be more suitable in the context of hotel industry. It is fundamentally based on the basic SERVQUAL model with some additions as Parasuraman et al. (1993) claimed its adaptability in any service industry. Over and above of the main quality dimensions of Parasuraman et al. (1988), this research adds three more variables; "products", "location" and "waiting time". Products will be looked in the light of variety and quality, which means the different variations of a product-brand that a hotel offers and their state when purchased. Location is with regard to its accessibility and physical environment, and waiting time for service delivery. Hence, modified SERVQUAL model with eight dimensions; tangibles, reliability, responsiveness, assurance, empathy, products, location and waiting time.

\subsection{Hypotheses}

H1: There is significance difference between expected and actual service attributes i.e. tangibility.

H2: There is significant difference between expected and actual quality service attribute i.e. reliability.

H3: There is significant difference between expected and actual service quality attribute i.e. responsiveness.

H4: There is significant difference between expected and actual service quality attribute i.e. assurance.

H5: There is significant difference between expected and actual service quality attribute i.e. empathy.

H6: There is significant difference between expected and actual customer service.

H7: There is significance difference between the mean score of Punjab and KPK customers on service quality attributes.

H8: There is significance difference between the mean score of KPK and Islamabad customers on service quality attributes.

H9: There is significance difference between the mean score of Punjab and Islamabad customers on service quality attributes.

\section{Research Methodology}

\subsection{Population}

The population frame for the study has been stratified on the bases of geography and the status level of the hotels located in selected cities of Khyber Pakhtunkhwa, Islamabad and Lahore. However, the hotels included in the population are those which have restaurants and living accommodation both. The sample of hotel was comprised of 10 hotels at each location and 20 customers at each hotel were investigated as respondents. 


\subsection{Sample Frame}

Initial stratification was based on the geographical basis with the strata of Peshawar, Islamabad and Lahore. Thereafter, hotels were stratified on the bases of their magnitude and facilities, grouping in to two strata i.e. Group one composed of hotels falling in 5 stars and 4 stars hotels. Group-2 comprises of all other hotels having restaurant as well as living rooms for the customers.

\section{Table 1: Sample Khyber Pakhtunkhwa}

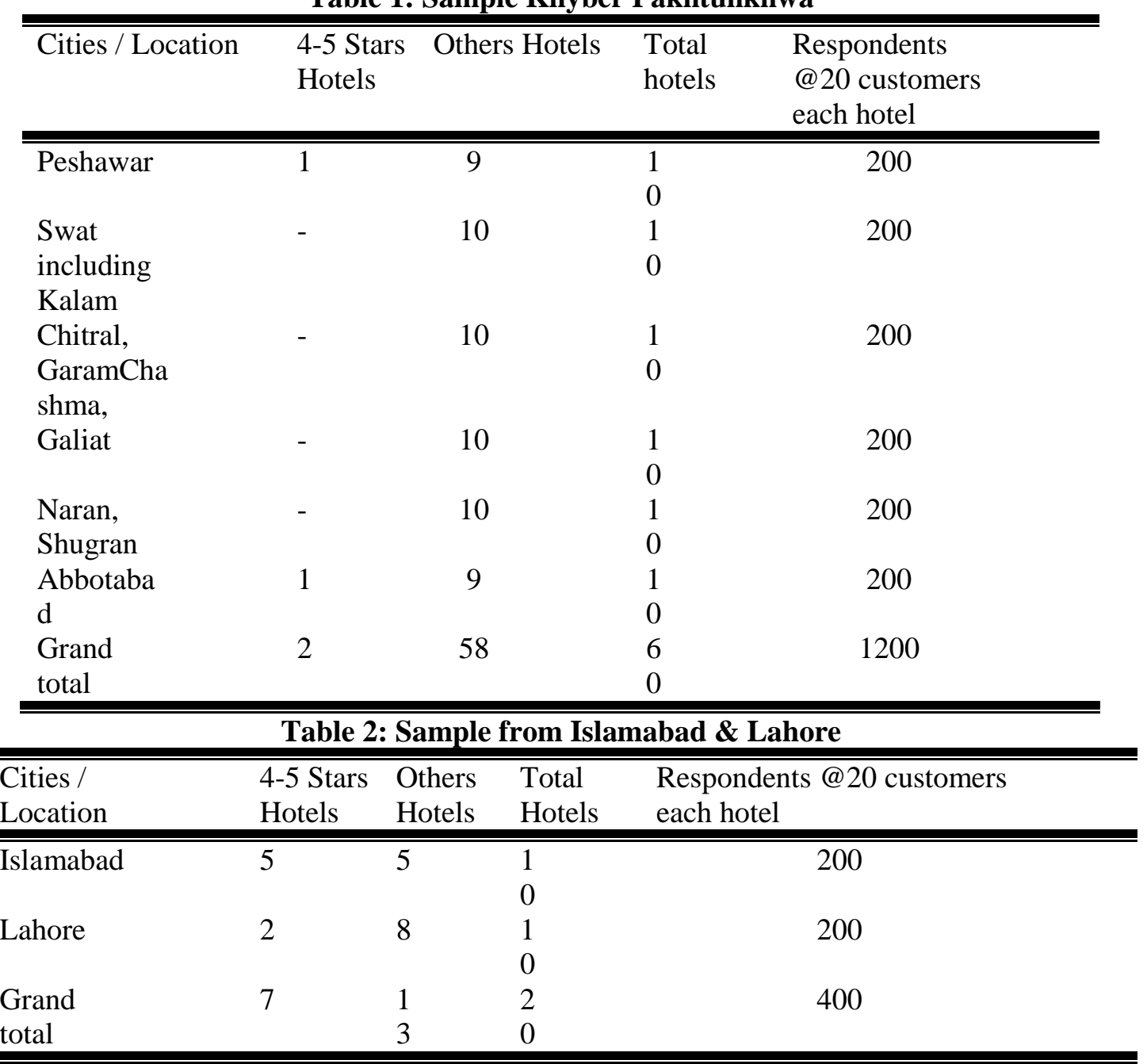

\subsection{Data Collection:}

In order to gather the primary data, it is very important to have an appropriate sample size to generate the research outcomes but helpful in ensuring the validity of the research results (Thomas, 1997). In this regard 1600 customers were selected and conveniently contacted by the researcher in order to get the questionnaires filled. The researcher selected the respondents of the survey through convenient sampling technique (Wilkinson and Birmingham, 2003). The numbers of constructs in the final questionnaire for this study were adopted from Boon and Rompho (2012) and modified suiting to local settings. 


\section{Analysis}

Table 3: Demographics

\begin{tabular}{|c|c|c|}
\hline Gender & Frequency & Percent \\
\hline Male & 788 & 55.1 \\
\hline Female & 641 & 44.9 \\
\hline Total & 1429 & 100.0 \\
\hline Age & Frequency & Percent \\
\hline $17-27$ years & 823 & 57.6 \\
\hline 28-38 years & 151 & 10.6 \\
\hline $\begin{array}{l}39 \text { and } \\
\text { above }\end{array}$ & 455 & 31.8 \\
\hline Total & 1429 & 100.0 \\
\hline $\begin{array}{c}\text { Qualificatio } \\
\text { n }\end{array}$ & Frequency & Percent \\
\hline Pakistani & 1401 & 98.0 \\
\hline Foreigners & 28 & 2.0 \\
\hline Total & 1429 & 100.0 \\
\hline Cities & Frequency & Percent \\
\hline Peshawar & 328 & 23.0 \\
\hline Abbottabad & 346 & 24.2 \\
\hline SWAT & 128 & 9.0 \\
\hline Galiat & 256 & 17.9 \\
\hline Naran & 104 & 7.3 \\
\hline Chitral & 22 & 1.5 \\
\hline Lahore & 100 & 7.0 \\
\hline Rawalpindi & 99 & 6.9 \\
\hline Islamabad & 46 & 3.2 \\
\hline Total & 1429 & 100.0 \\
\hline
\end{tabular}

The above captioned table represents the demographics of the respondents. Total strength of Male respondents were 788 out of 1429 members that represent $55.1 \%$ of the total whereas; female represents 641 out of 1429 participants that depict $44.9 \%$ of the total sample. Participants with the ages of 17-27 years represent 823 out of 1429 members that depict $57.6 \%$ of the total sample 1429. From 28-38 years of ages group members represents 151 out of 1429 members that portray $10.6 \%$ of the total sample 1429. From 39 and above years of ages group members represents 455 out of 1429 members that portray $31.8 \%$ of the total sample 1429. Pakistani and foreigners participants were 1401 and 28 out of 1429 members. Furthermore, it represents the percentage of $98 \%$ and $2 \%$ respectively. In Peshawar, Abbottabad, Swat, Galiat, Naran, Chitral, Lahore, Rawalpindi and Islamabad hotels there were 328, 346, 128, 256, 104, 22 , 100,99 and 46 customers out of 1429 who took part in the survey. 


\subsection{Mean Difference}

\subsubsection{One Way ANOVA}

The researcher used one way ANOVA to measure the difference between the views of customer of Peshawar, Abbottabad, Swat, Galiyat, Naran and Chitral Hotels about the Actual and Expected Service Quality.

Table 4: Difference Between the Views of Customer- ANOVA

\begin{tabular}{|c|c|c|c|c|c|c|}
\hline & & $\begin{array}{c}\text { Sum of } \\
\text { Squares }\end{array}$ & Df & Mean Square & $\mathbf{F}$ & Sig. \\
\hline \multirow{3}{*}{ Actual Tangibility } & Between Groups & 3.310 & 5 & .662 & .850 & .514 \\
\hline & Within Groups & 1107.763 & 1423 & .778 & & \\
\hline & Total & 1111.074 & 1428 & & & \\
\hline \multirow{3}{*}{ Actual Reliability } & Between Groups & 7.442 & 5 & 1.488 & 1.535 & .176 \\
\hline & Within Groups & 1379.605 & 1423 & .970 & & \\
\hline & Total & 1387.047 & 1428 & & & \\
\hline \multirow{3}{*}{$\begin{array}{l}\text { Actual } \\
\text { Responsiveness }\end{array}$} & Between Groups & 10.085 & 5 & 2.017 & 3.196 & .007 \\
\hline & Within Groups & 898.102 & 1423 & .631 & & \\
\hline & Total & 908.188 & 1428 & & & \\
\hline \multirow{3}{*}{ Actual Assurance } & Between Groups & .568 & 5 & .114 & .160 & .977 \\
\hline & Within Groups & 1009.980 & 1423 & .710 & & \\
\hline & Total & 1010.548 & 1428 & & & \\
\hline \multirow{3}{*}{ Actual Empathy } & Between Groups & 3.419 & 5 & .684 & 1.037 & .394 \\
\hline & Within Groups & 938.272 & 1423 & .659 & & \\
\hline & Total & 941.692 & 1428 & & & \\
\hline \multirow{3}{*}{ Actual CS } & Between Groups & .192 & 5 & .038 & .039 & .999 \\
\hline & Within Groups & 1387.485 & 1423 & .975 & & \\
\hline & Total & 1387.677 & 1428 & & & \\
\hline \multirow{3}{*}{ Expected Tangibility } & Between Groups & 1.400 & 5 & .280 & .437 & .823 \\
\hline & Within Groups & 912.207 & 1423 & .641 & & \\
\hline & Total & 913.607 & 1428 & & & \\
\hline \multirow{3}{*}{ Expected Reliability } & Between Groups & 3.922 & 5 & .784 & .766 & .575 \\
\hline & Within Groups & 1457.920 & 1423 & 1.025 & & \\
\hline & Total & 1461.842 & 1428 & & & \\
\hline \multirow{3}{*}{$\begin{array}{l}\text { Expected } \\
\text { Responsiveness }\end{array}$} & Between Groups & 1.952 & 5 & .390 & .551 & .737 \\
\hline & Within Groups & 1007.780 & 1423 & .708 & & \\
\hline & Total & 1009.732 & 1428 & & & \\
\hline \multirow{3}{*}{ Expected Assurance } & Between Groups & 2.302 & 5 & .460 & .755 & .583 \\
\hline & Within Groups & 867.850 & 1423 & .610 & & \\
\hline & Total & 870.152 & 1428 & & & \\
\hline \multirow{3}{*}{ Expected Empathy } & Between Groups & .408 & 5 & .082 & .151 & .980 \\
\hline & Within Groups & 769.066 & 1423 & .540 & & \\
\hline & Total & 769.474 & 1428 & & & \\
\hline \multirow{3}{*}{ Expected CS } & Between Groups & .255 & 5 & .051 & .146 & .981 \\
\hline & Within Groups & 497.233 & 1423 & .349 & & \\
\hline & Total & 497.489 & 1428 & & & \\
\hline
\end{tabular}

The above table shows the difference between the views of customer of Peshawar, Abbottabad, Swat, Galiyat,Naran and Chitral hotels about the actual and expected service quality. The difference between and within the group members of value of actual tangibility, reliability, responsiveness, assurance, empathy and customer satisfaction was found $(\mathrm{F}=.850, \mathrm{P}=.514),(\mathrm{F}=1.535, \mathrm{P}=.176),(\mathrm{F}=3.196, \mathrm{P}=.007),(\mathrm{F}=$ $.160, \mathrm{P}=.977),(\mathrm{F}=1.037, \mathrm{P}=.394)$ and $(\mathrm{F}=.039, \mathrm{P}=.999)$ respectively this demonstrates that there are no significant differences between the groups' mean scoresof customersabout the actual tangibility, reliability, assurance, empathy and customer 
satisfaction the only actual responsiveness of customers value was found significant which depicted that there are significant differences between the groups' mean scores of actual responsiveness. On the other sidethe difference between and within the group members of value of expected tangibility, reliability, responsiveness, assurance, empathy and customer satisfaction was found $(\mathrm{F}=.437, \mathrm{P}=.823),(\mathrm{F}=766, \mathrm{P}=.575),(\mathrm{F}=.551, \mathrm{P}=$ $.737),(\mathrm{F}=.755, \mathrm{P}=.583),(\mathrm{F}=.151, \mathrm{P}=.980)$ and $(\mathrm{F}=.146, \mathrm{P}=.981)$ respectively this demonstrates that there are no significant differences between the groups' mean scores of customers of Peshawar, Abbottabad, Swat, Galiyat, Naran and Chitral Hotels about the Actual and Expected Service Quality about the expected tangibility, reliability, responsiveness, assurance, empathy and customer satisfaction.

\subsection{Paired Sample T-test}

In statistics, a paired difference test is a type of test that is used when comparing two sets of measurements to assess whether their population means differ. The actual and expected service quality is measured via paired sample T-test. The data was verified by consuming the (paired samples t-test) for mean difference. This investigation describes significance and instability of the variables, through molds that the circulation of the variable is usual and that modification of variable is equal in mutually usual of people. The (test statistic) is as follows.

Where

$$
t=\frac{\mathrm{d}}{\mathrm{S} d \sqrt{n}}(\text { Chaudhry and Kamal, 2004) }
$$

$\mathrm{d}$ is sample mean change.

$\mathrm{n}$ is numeral of sample variance and

$\mathrm{S}_{\mathrm{d}}$ is the standard deviation of $\mathrm{d}$

Formulations for $\mathrm{d}$ and $\mathrm{S}_{\mathrm{d}}$ are as follows:

$$
\begin{gathered}
\mathbf{d}=\sum \mathbf{d}_{\mathbf{1}} / \mathbf{n} \\
\mathbf{S}_{\mathbf{d}}=\sqrt{ } \sum \mathbf{d d - d}_{\mathbf{1}}{ }^{2} / \mathbf{n}-\mathbf{1}
\end{gathered}
$$

Table 5: Paired Samples Statistics for Expected and Actual Service Quality

\begin{tabular}{lcccccc}
\hline Pair & Mean & $\mathbf{N}$ & Std. Deviation & Std. Error Mean & t & Sig \\
\hline Expected Tangibility- Actual & 3.56 & 1429 & .79986 & .02116 & 20.5 & .000 \\
Tangibility & 4.11 & 1429 & .88208 & .02333 & & \\
\hline Expected Reliability- Actual & 4.07 & 1429 & 1.01178 & .02677 & 4.99 & .000 \\
Tangibility & 4.25 & 1429 & .98556 & .02607 & & \\
\hline Expected Responsiveness - & 4.34 & 1429 & .84089 & .02224 & 38.2 & .000 \\
Actual Responsiveness & 3.40 & 1429 & .79749 & .02110 & & .000 \\
\hline Expected Assurance - Actual & 4.17 & 1429 & .78061 & .02065 & 16.8 & .000 \\
Assurance & 3.67 & 1429 & .84123 & .02225 & & .001 \\
\hline Expected Empathy- Actual & 3.77 & 1429 & .73406 & .01942 & 3.37 & .02148 \\
Empathy & 3.67 & 1429 & .81206 & .0206 & \\
\hline Expected Customer Service- & 3.66 & 1429 & .59024 & .01561 & 22.8 & .000 \\
Actual Customer Service & 3.15 & 1429 & .98578 & .02608 & & \\
\hline
\end{tabular}

The outcomes of Paired samples t-test used for measure the expected and actual service quality. The mean score of expected tangibility is found 3.56 and actual tangibility is found 4.11. It demonstrates that actual tangibility is greater than expected tangibility. The SD (Standard deviation) is greater in the actual tangibility as compared to expected tangibility. The $t$ value is found 20.5 and significant value is found .000 which shows that considerable variation has been discovered in actual and expected tangibility. So, alternate hypothesis is accepted which depicted: There is significance difference 
between expected and actual service attributes i.e. tangibility. The mean score of expected reliability is found 4.07 and actual reliability is found 4.25. It demonstrates that actual reliability is greater than expected reliability. The SD (Standard deviation) is lesser in the actual reliability as compared to expected reliability. The $t$ value is found 4.99 and significance value is found .000 which shows that substantial variation have been discovered in actual and expected service quality attribute i.e. reliability. So, alternate hypothesis is accepted which depicted: There is significant difference between expected and actual quality service attribute i.e. reliability.The mean score of expected responsiveness is found 4.34 and actual responsiveness is found 3.40. It demonstrates that actual responsiveness is lesser than the expected reliability. The SD (Standard deviation) is lesser in the actual reliability as compared to expected reliability. The t value is found 38.2 and significance value is found .000 which shows that significant variation have been discovered in actual and expected service quality attribute i.e. responsiveness. So, alternate hypothesis is accepted which depicted: There is significant difference between expected and actual service quality attribute i.e. responsiveness. The mean score of expected assurance is found 4.17 and actual assurance is found 3.67. It shows that actual assurance is lesser than the expected assurance.

The SD (Standard deviation) is lesser in the actual assurance as compared to expected assurance. The $t$ value is found 16.8 and significance value is found .000 which shows that significant variation have been discovered in actual and expected service quality attribute i.e. assurance. So, alternate hypothesis is accepted which depicted: There is significant difference between expected and actual service quality attribute i.e. assurance.The mean score of expected empathy is found 3.77 and actual empathy is found 3.67. It shows that actual empathy is lesser than the expected empathy. The SD (Standard deviation) is greater in the actual reliability as compared to expected reliability. The $\mathrm{t}$ value is found 3.37 and significance value is found .001 which shows that significant variation have been discovered in actual and expected service quality attribute i.e. empathy. So, alternate hypothesis is accepted which depicted: There is significant difference between expected and actual service quality attribute i.e. empathy.The mean score of expected customer service is found 3.66 and actual customer service is found 3.15. It shows that actual customer service is lesser than the expected customer service. The SD (Standard deviation) is greater in the actual reliability as compared to expected reliability. The $\mathrm{t}$ value is found 22.8 and significance value is found .000 which shows that significant variation have been discovered in actual and expected customer service. So, alternate hypothesis is accepted which depicted: There is significant difference between expected and actual customer service.

Table 6: Paired Samples Statistics for Comparing the Mean Score of KPK, Punjab and Islamabad Customer

\begin{tabular}{lcccccc}
\hline Pair & Mean & $\mathbf{N}$ & Std. Deviation & Std. Error Mean & t & Sig \\
\hline KPK- Punjab & 4.12 & 1429 & .882 & .023 & 6.03 & .000 \\
& 4.25 & 1429 & .986 & .026 & & \\
\hline KPK-Islamabad & 4.12 & 1429 & .882 & .023 & 23.7 & .000 \\
& 3.40 & 1429 & .797 & .021 & & \\
\hline Punjab-Islamabad & 4.25 & 1429 & .986 & .026 & 28.1 & .000 \\
& 3.40 & 1429 & .797 & .021 & & \\
\hline
\end{tabular}


The Paired samples t-test used to compare the mean score difference about the customers of KPK, Punjab and Islamabad Pakistan. The mean score of KPK customers is found 4.12 and Punjab customers are found 4.25. It demonstrates that the mean score of Punjab customers is greater than mean score of KPK hotel customers on service quality. The SD (Standard deviation) is greater in the Punjab customers as compared to KPK customers. The $t$ value is found 6.03 and significant value is found .000 which shows that considerable variation has been discovered in KPK and Punjab customers on service quality attributes. So, alternate hypothesis is accepted which depicted: There is significance difference between the mean score of Punjab and KPK customers on service quality attributes.The mean score of KPK customers is found 4.12 and Islamabad customers are found 3.40. It demonstrates that the mean score of KPK customers is greater than mean score of Islamabad hotel customers on hotel service quality attributes. The SD (Standard deviation) is greater in the KPK customers as compared to Islamabad customers. The $\mathrm{t}$ value is found 23.7 and significant value is found .000 which shows that considerable variation has been discovered in KPK and Islamabad customers on service quality attributes. So, the alternate hypothesis is accepted which depicted: There is significance difference between the mean score of KPK and Islamabad customers on service quality attributes.The mean score of Punjab customers is found 4.25 and Islamabad customers are found 3.40. It demonstrates that the mean score of Punjab customers is greater than mean score of Islamabad hotel customers on service quality attributes. The SD (Standard deviation) is greater in the Punjab customers as compared to Islamabad customers. The $t$ value is found 28.1 and significant value is found .000 which shows that considerable variation has been discovered in KPK and Islamabad customers on service quality attributes. So, alternate hypothesis is accepted which depicted: There is significance difference between the mean score of Punjab and Islamabad customers on service quality attributes.

\section{Discussion}

The population frame for the study has been stratified on the bases of geography and the status level of the hotels located in selected cities of Khyber Pakhtunkhwa, Islamabad and Lahore. However, the hotels included in the population are those which have restaurants and living accommodation both. The sample of hotel was comprised of 10 hotels at each location and 20 customers at each hotel were investigated as respondents of the study survey. Initial stratification was based on the geographical basis with the strata of Peshawar, Islamabad and Lahore. Thereafter, hotels were stratified on the bases of their magnitude and facilities, grouping in to two strata i.e. Group one composed of hotels falling in 5 stars and 4 stars hotels. Group- 2 comprises of all other hotels having restaurant as well as living rooms for the customers. The researcher used one way ANOVA to measure the difference between the views of customer of Peshawar, Abbottabad, Swat, Galiat,Naran and Chitral hotels about the actual and expected service quality. The difference between and within the group members of value of actual tangibility, reliability, responsiveness, assurance, empathy and customer satisfaction was found that there are no significant differences between the groups' mean scoresof customersabout the actual tangibility, reliability, assurance, empathy and customer satisfaction the only actual responsiveness of customers value was found significant which depicted that there are significant differences between the groups' mean scores of actual responsiveness.On the other sidethe difference between and within the group 
members of value of expected tangibility, reliability, responsiveness, assurance, empathy and customer satisfaction was found that there are no significant differences between the groups' mean scores of customers of Peshawar, Abbottabad, Swat, Galiat, Naran and Chitral Hotels about the Actual and Expected Service Quality about the expected tangibility, reliability, responsiveness, assurance, empathy and customer satisfaction. The actual and expected service quality is measured via paired sample T-test.

The statistical analysis amid expected tangibility and actual tangibility reveals that there is significance difference between expected and actual service attributes i.e. tangibility.The statistical analysis amid expected reliability and actual reliability reveals that there is significant difference between expected and actual quality service attribute i.e. reliability.The statistical analysis amid expected responsiveness and actual responsiveness is found and outcome reveals that there is significant difference between expected and actual service quality attribute i.e. responsiveness. The mean score of expected assurance and actual assurance depicted that there is significant difference between expected and actual service quality attribute i.e. assurance.The mean score of expected empathy and actual empathy depicted that there is significant difference between expected and actual service quality attribute i.e. empathy. The mean score of expected customer service and actual customer service depicted that there is significant difference between expected and actual customer service.The Paired samples t-test used to compare the mean score difference about the customers of KPK, Punjab and Islamabad Pakistan. The mean score of KPK and Punjab customers depicted that there is significance difference between the mean score of Punjab and KPK customers on service quality attributes. The mean score of KPK customers and Islamabad customers reveals that there is significance difference between the mean score of KPK and Islamabad customers on service quality attributes.The mean score of Punjab customers is and Islamabad customers are found that there is significance difference between the mean score of Punjab and Islamabad customers on service quality attributes.

\subsection{Recommendations}

Based on the analysis and discussions/ findings of this chapter, with the purpose of improving the performance ofhotels of Pakistan competitiveness through customer'ssatisfaction, the research study offers following recommendations related to each factor affecting hotels of Pakistan. Hotel staff training solutions need to be implemented continuously. For example, hotels of Pakistan should create favorable conditions for their staff to update their knowledge regularly, make sense of responsibility for their work, and improve the processing skills and efficiency. Besides, hotels of Pakistan should pay particular attention to in front employees to equip them with knowledge about customer service skills, practice patience, confidence to solve problems of customer, calm and cheerful attitude with customers even when facing work pressure. Efforts shall be taken to ensure quality services. Such efforts would add in to customers' satisfaction on one hand and build image of the hotel line on the other. In order to improve these aspects hotels of Pakistan should focus on criteria key points of the hotel quality service planning and controlling. Improving price and convenience perspective price is the significant factor that hotels of Pakistan should focus on. Relooking at the cost and convenience relationship which must be in customers favor. This would add in to the sustainability of the competitive advantage of the hotels of Pakistan. Although hotels of Pakistan is assessed quite well by customers for this factor 
however hotels of Pakistan is facing the challenges that needs to overcome to continuity of driving on price. The appearance of five star hotels with the same market segment has created real kick to force other hotels working in Pakistan to have clearly competitive strategies. Besides the continues incur losses for recent years, hotels of Pakistan must carefully calculate to deal with the competition on price.

\subsection{Limitations}

There are certain limitations of this study. One imperfection originates from the quantitative methodological worldview of factual generalizability, is that, the most quantitative studies start with an obscure thought of an objective populace which is not very much characterized in a large portion of the exploration concentrates on and even they will probably have an unequivocal open populace (Kerlinger and Lee, 2000). Due to smaller sample size on cross sectional basis this study is limited in terms of factual generalizability and the result might be biased. Moreover, this study has also limitation pertaining to the issue of analytical generalizability because the researcher didn't used confirmatory strategies in terms of checking all the assumptions of the implemented multiple regression tests.

\subsection{Futures Areas for Researches}

The area for additional and further researchis an in-depthexamination of almost all the Motels working in Pakistan to take hold of some of the other factors contributing towards thecustomer service quality attributes and customer satisfaction and loyalty. In future the present hypotheses should be studied in numerous samples from different other Hotels of Pakistan on longitudinal basis. In future, some moderation and mediating variable also incorporated.

\subsection{Conclusion}

Every business endeavors to achieve customer satisfaction and cultivate customer loyalty. Customer satisfaction is prelude to customer loyalty and cost and service quality affects the degree of customer satisfaction. There is no denying the fact that consumers tend to deliberate the relative relationship between the cost and their expectations about the performance of the product and these expectations become more quality oriented in case of service industry. This is especially true in case of Hotel service as customer's evaluation of service quality and the resulting level of satisfaction are perceived to affect bottom line measures of Hotel success. Service quality is one of the best models for evaluating customers ${ }^{e e}$ expectations and perceptions. If the customer is not satisfied, due to the negative experience, the client will probably switch to another Hotel in future travel. So Hotel managers should better serve their customers, monitor and develop service quality to achieve the highest level of their customers' satisfaction.

The underlying focus of the research study was to approach the potential and real customers of the hotels of Pakistan and to measure their perceived level of service quality and its impact on their level of satisfaction level via SURVEQUAL dimensions. The objective of the study was to measure the degree of relationships between Hotel service quality and customer satisfaction and business performance. The objective of the study was to comparatively analyze the customer perceptions about hotels working in the diverse locations of Pakistan. The result of the study also reveals that there exists a strong significant difference between the customers the mean score of Punjab, KPK and Islamabad customers on service quality 
attributes.Furthermore, hotels of Pakistan ought to give careful consideration to in front representatives to furnish them with learning about client administration aptitudes, rehearse persistence, certainty to take care of issues of client, quiet and lively disposition with clients notwithstanding when confronting them. Improvement of check-in (registration process) and cost and accommodation is mandatory for efficient Hotel. In hotel craft operation dependably exists high risks that are hard to anticipate. Hotels of Pakistan ought to likewise pay consideration on the association between the hotel accommodation and other sort of transportation at the destination, for example, auto transportations, and so on to make the most ideal conditions for its travelers. The transportation office requires that hotel crafts take after their agreement of carriage, which is the legitimate understanding amongst travelers and the carrier, however they don't let them know what to put in it. Carriers ought to deliberately incorporate their client responsibilities in the agreement, which cover how travelers will be dealt with if there's a deferral or an administration intrusion.

\section{References}

Andersen, B.; Henriksen, B \& Aarseth, W. (2006).Holistic Performance Management: AnIntegrated framework. International Journal of Productivity and Performance Management, Vol. 55(1), p. 61-78

Asher, M. (1996). Managing Quality in the service sector. London: Kogan Page.

Antony, F.; Antony, F. F. \& Ghosh, S. (2004). Evaluating service quality in a UK hotel chain:a case study.International Journal of Contemporary Hospitality Management, Vol.16(6),p. 380-384.

Atkinson, H \& Brown, J. B. (2001).Rethinking performance measure: assessing progress inUK hotels. International Journal of Hospitality Management, Vol.13(3), p.128135.

Bazeley, P. (2004). Issues in mixing qualitative and quantitative approaches to research.In Buber, R. and Gadner, J. (Eds).Applying qualitative methods to marketing managementresearch. Basingstoke: Palgrave McMillan.

Blaikie, H. R. (2000). Toward a purposeful approach to the constant comparative method in the analysis of qualitative interviews. Proceedings of the 5th International Conference for Methodologies in Social Sciences, Cologne.

Bolton, R.N. \& Drew, J. H. (1991). A longitudinal analysis of the impact of services changeson consumer attitudes.Journal of marketing, Vol. 55, pp. 1-9.

Carson, D. \& Coviello, N. (1996).Qualitative research issues at the marketing orentrepreneurship interface. Marketing Intelligence and Planning, Vol. 14(6), p. 51-8.

Clark, E; Tynan, C. \& Money, A. (1994).'Senior Managers Views on Quality: a Strategic Perspective. Journal of Strategic Management. Vol. 2, pp.61-84.

Creswell, J. W. (2003). Research design: Qualitative, quantitative and mixed methodapproaches $\left(2^{\text {nd }}\right.$ Ed. $)$. Thousand Oaks: Sage.

Cokins, G. (2006).Performance Management. In Adkins, T (Ed). Case studies in performance management: A guide from the experts. New Jersey: John Wiley and Sons.

Glaser, N. (1999). The future of grounded theory. Qualitative Health Research, Vol. 9(6) pp. $836-45$ 
Crosby, P. B. (1984). Quality Without Tears. New York: New American Library

Ekinci, Y. \& Riley M. (2001).Validating quality dimensions. Annals of Tourism Research, Vol. 28(1), pp.202-223.

Getty, J. M. \& Getty, R. L. (2003).Lodging Quality Index (LQI): Assessing customers'perceptions of quality delivery. International Journal of Contemporary HospitalityManagement, Vol. 15(2), pp. 94-104.

Grbich, C. (1999). Qualitative research in health: An introduction. Beverley Hills: Allen and Unwin and Sage International.

Gronroos, C. (1984). Service Management and Marketing. Lexington, MA: Lexington Books.

Harrington, D. \& Akehurst, G. (1996). Service Quality and Business performance in the UKHotel Industry. International Journal of Hospitality Management, Vol. 15(3), p. 283-298.

Harrington, D. \& Akehurst, G. (2000).An empirical study of service quality implementation. The Services Industry Journal, Vol. 20, No. 2, pp. 133-156.

Howarth \& Howarth. (1988).Hotels of the future (p. 25).Howarth and Howarth UK

Jacobsen, R. \& Aacker, D. (1987). The strategic role of product quality. Journal of Marketing, Vol. 51, p.31-44.

Johns, N. (1999). Quality Management.In Brotherton, B (ed.) (1999).The Handbook ofContemporary Hospitality Management Research (pp. 333-349).Chichester: John Wiley \&sons Ltd.

Juran, J.M. (1988). Juran on planning for quality. New York: The Free Press.

Juran, J. M. (1982). Upper Management and Quality. New York: Juran Institute.

Kaplan, R.S. \& Norton D. P. (1992). The balanced scorecard: measures that driveperformance. Harvard Business review January-February, p. 71-80

Kerfoot, O. \& Knights, D. (1995). Empowering the "Quality Worker: The Seduction and Contradiction of the Total Quality Phenomenon'. In A. Wilkinson and H. Willmott (eds). Making Quality Critical: New Perspective on organizational change. London: Routledge.

Kvale, S. (1996). Interviews: an introduction to qualitative interviewing. Thousand Oaks: Sage.

Monks.K.; Sinnott, A. \& Buckley, F. (1996). Implementing Quality Initiatives in Ireland: The practice in Service Organizations QUIS Annual Conference, Madrid, April

Morgan, R. E. \& Piercy N. (1996). Competitive Advantage through People'.British Journal of Management, Vol. 7. pp. 231-45.

Nebel, E. C. \& Schaffer, J. D. (1992).Hotel strategic planning at the Business and UnitLevel in the USA. In R. Teare and M. Olsen (eds.). International Hospitality Management Corporate Strategy in practice. New York: John Wiley \&Sons. pp. 228-54.

Neely, A. (1998). Measuring Business Performance: Why, what and how. London: The Economist Books.

Parasuraman, A., Zeithaml, V. A. \& Berry, L.L. (1985). A conceptual model of service qualityand its implication for future research. Journal of Marketing, Vol.49, p. 41-50.

Parasuraman, A., Zeithaml, V. A. \& Berry, L.L. (1988).SERVQUAL: A multi-item scale formeasuring consumer perceptions of service quality. Journal of Retailing, Vol. 
64, Spring, p.12-40.

Parasuraman, A. (2002). Service Quality and Productivity: a synergistic perspective. Managing Service Quality, Vol. 1(1), p. 6-9.

Patton, M. Q. (1990). Qualitative Evaluation and Research Methods. Newbury Park: SagePublications.

Perry, C. (2001). Case Research in Marketing. The Marketing Review, Vol. 1, p. 303-323.

Phillips, P. A. (1999). Performance Measurement systems and hotels: a conceptual framework. Hospitality Management, Vol. 18, p. 171-182.

Powell. T.C. (1995). Total Quality as Competitive Advantage: A Review and empirical study. Strategic Management Journal.Vol. 16.Pp. 15.-3 7.

Presbury, R. Fitzgerald, A. \& Chapman, R. (2005). Impediments to Improvements in Service Quality in Luxury Hotels. Managing Service Quality, Vol. 15(4), p. 357373

Pruett, M. \& Thomas, H. (1996). Thinking about Quality and it's Links with StrategicManagement. European Management Journal. Vol. 14(1), pp.37-46

Olian.J.D. \& Rynes, S.L. (1991). Making 'otal Quality Work: Aligning Organizational Processes. Performance Measures and Stakeholders'. Human Resources Management.Vol. 30(3). pp. 303-33.

O'Neill, M. (2001).Measuring Service Quality and Customer Satisfaction. In Kandampully, J.; Mok, C.; Sparks, B. (eds). (2001). Service Quality Management in Hospitality, Tourismand Leisure. New York: The Haworth Hospitality Press.

Rajagopal, S.; Balan, S. \& Scheuing, E.E. (1995). Total Quality Management: Quick Fix or Sound Sense, Total Quality Management. Vol. 6(4), pp.335-44.

Reichheld, F. F. \& Sasser, E. W. (1990). Zero defections: quality comes to services. Harvard Business Review, Vol. 68(5), p. 105-111.

Robinson, S. (1999). Measuring Service Quality: Current Thinking and Future Requirements. Marketing Intelligence and Planning, Vol. 17(1), pp. 21-32.

Rust, R.T. \& Oliver, R.L. (eds), (1994). Service Quality: New, Directions and practice. London: Sage Publications

Soteriou, A. C. \& Zeinos, S. A. (2000). On the impact of quality on performance: first empirical evidence from the finance industry. [On-Line]. http:/Iwww.ise.nus.edu.sg/proceedings/apors2000/full papers/2 1 -05-fp.htm

Wilkinson, A. (1992). The Other Side of Quality: "Soft" Issues and the Human Resource Dimension. Total Quality Management Vol. 3(3), pp.323-9.

Wilkinson, A. \& Wilmott, H. (eds), (1995). Making quality critical. London: Routledge.International CHRIE Conference-Refereed Track, Event 11 [2010]pp. $1-32$,

Yin, R. K. (2008).Case Study Research: Design and Methods (Applied Social ResearchMethods) ( $4^{\text {th }}$ Ed.). Thousand Oaks: Sage Publications.

Zairi, M. Letza, S.R. \& Oakland, J.S. (1994).TQM: Its impact on bottom line Results, London: Technical Communications.

Zeithaml, V. A. (2000). Service quality, profitability and the economic worth of customers: What we know and what we need to learn. Journal of Marketing Science, Vol. 28, No. 1, p 67-85

Zeithaml, V., Parasuraman, A. \& Berry, L.L. (1990). Delivering quality service. New York: Free Press 